Itinéraires Itinéraires

Littérature, textes, cultures

\title{
Partners in Crime: Readers, Translators, Characters and the Promotion of a Genre
}

David Platten

\section{(2) OpenEdition}

Journals

\section{Electronic version}

URL: http://journals.openedition.org/itineraires/2623

DOI: 10.4000/itineraires.2623

ISSN: 2427-920X

\section{Publisher}

Pléiade

\section{Electronic reference}

David Platten, "Partners in Crime: Readers, Translators, Characters and the Promotion of a Genre », Itinéraires [Online], 2014-3 | 2015, Online since 25 February 2019, connection on 02 May 2019. URL http://journals.openedition.org/itineraires/2623 ; DOI : 10.4000/itineraires.2623

This text was automatically generated on 2 May 2019.

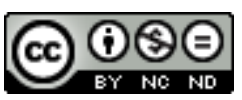

Itinéraires est mis à disposition selon les termes de la licence Creative Commons Attribution - Pas d'Utilisation Commerciale - Pas de Modification 4.0 International. 


\title{
Partners in Crime: Readers, Translators, Characters and the Promotion of a Genre
}

\author{
David Platten
}

1 “Le roman noir est l'avenir de la fiction." Patrick Raynal's declaration, issued in 1995, challenged the views of traditionalists who believed that the national culture was being undermined by the forces of multiculturalism, the audiovisual media, and the renunciation of a glorious literary heritage. ${ }^{1}$ Twelve years later a group of French writers and intellectuals signed the "Pour une 'littérature-monde' en français" manifesto, acknowledging the pre-eminence of a global literary culture, of which French-language literature should be a distinctive part. ${ }^{2}$ Twenty years on, the popularity of crime fiction continues to soar, in paperback and on reading tablets, on small and large screens across the world; 2013 saw a 6\% rise in the number of crime novels published in France compared with the previous year's figures, and this in the context of a dip in the overall productivity of the French book trade. ${ }^{3}$ Moreover, in the sphere of European crime literature in translation, the eminent publisher Christopher MacLehose has forecasted that a new generation of French-language writers, including Antonin Varenne, Hervé Le Corre, Dominique Sylvain, and the Swiss Joël Dicker, is poised to sweep all before them. ${ }^{4}$ In the light of the commercial and critical success enjoyed firstly by French crime fiction within its national boundaries and secondly by crime stories with local characteristics that have reached global audiences, it is timely to reassess what is beginning to look like a new cultural imperialism. The starting-point for this discussion will be the radical message encrypted in Raynal's 1995 prophecy, namely that the literary idiom of the modern crime narrative is so infectious that it will increasingly shape the production and consumption of the mainstream prose fiction of the future. Rowing back from this absolutist position, I shall argue that contemporary crime fiction has been successful because it has retained and protected a strong generic identity that has its roots in the 19th century. With regard to contemporary French and global literary culture, this essay will explore the extent to which innate properties of crime fictions guide the responses of readers but also facilitate the translation and transposition of these narratives to 
different national cultures. The argument will initially draw on evidence contained within a landmark publication, the two volumes of the Dictionnaire des littératures policières , edited by Claude Mesplède (2007). Then, with reference to Edgar Allen Poe's The Murders in the Rue Morgue (1841) and to the contemporary fiction of Fred Vargas, it will examine how, through their textual interactions, characters in crime narratives may function as proxies both for the reader, and for the translator. Finally the argument will be augmented through discussion of Pierre Bayard's "critique policière" and Luc Boltanski's ideas on the societal impacts of the genre.

\section{A Monument to Crime: the Dictionnaire des littératures policières}

2 For many years, and certainly since the prominence achieved in the 1960s and 1970s by the néo-polar school, French crime fiction has seemed like a terrier, snapping at the heels of the literary establishment. In the eyes of its detractors, the black jackets of the Série Noire heralded a satanic debasement of literary virtue, an attitude that was aided by some lascivious publicity and abetted by many of the house writers, who revelled in the image of belligerent cultural outsiders. This duality is an important feature of the politically and socially committed wing of the genre, described variously as the roman noir or polar, which, since the end of the Second World War, has been portrayed as butting against, or at least existing in contrast to, the literary mainstream, giving it a strong, cultural brand that other so-called minor literary genres have not managed to attain. Consequently, the crime literature industry has been able to ride economic peaks and troughs and en route has gradually infiltrated French cultural life. ${ }^{5}$ This presence has manifested itself in different ways that have been well documented, from the success of mainstream authors with roots in the crime series, to the proliferation of crime stories across different cultural media. ${ }^{6}$

3 The Dictionnaire des littératures policières has been published in two editions, firstly in 2003 and then again in 2007. ${ }^{7}$ With high production values matched by flawless editing, the volumes boast the trappings of an indispensable reference work, which, like any ambitious enterprise that draws on the combined knowledge of numerous experts, assumes a powerful, consensual authority. On the flipside, the reader must tolerate a diversity of styles and registers, as well as subtly different shades of opinion; the Dictionnaire, like all encyclopaedias, offers a kaleidoscopic rather than stable perspective on its subject matter. My analysis will deploy a simple metaphor for the reading process borrowed from the world of physics. Firstly let us imagine that the swirling patterns of the kaleidoscope are endowed with a centrifugal force, spinning outwards and thus compelling the reader to think about the information presented in a comparative context.

4 The vast majority of entries relate to the œuvres of writers and are written with an elegant concision, much like the entries to any good encyclopaedia or glossary of literary fiction. This correlates with the evidence of the considerable secondary literature devoted to the study of the crime genres. Beyond the rudiments of theme and plot, scholars and critics do not tend to differentiate between crime and mainstream literary fiction in the ways they choose to approach the primary material. There are some adjustments made on the basis of generic identity; for example, crime fiction offers 
particularly fertile ground for psychoanalytical readings, and in French studies it continues to generate rich pickings for cultural historians interested in the politics of memory and especially in the demystification of events during the Occupation. ${ }^{8}$ Still, as a general rule a crime narrative is apprehended much like any other novelistic mode, in function of its potential to enrich understanding of a prefabricated interest or set of interests lodged in the mind of the professional reader, which will often relate to broad, interdisciplinary themes such as trauma, memory, or gender. Procedurally, researchers into crime fiction follow the same channels as those who work on general literature, giving papers at conferences and writing articles in journals that tend to be either singleauthor or indeed single-text studies.

5 Let us now imagine that our contact with the text is imbued with a centripetal force that energises questions concerning the nature and status of the genre, and a very different picture emerges. The Dictionnaire performs a powerful validation of what, for the purposes of this essay, we might call the generic specificities of crime fiction. These features can be adumbrated by three adjectives: crime fiction is inclusive, international and immersive.

6 The Dictionnaire owes its existence to the efforts of a diverse constituency. Of the seventynine contributors listed on pages 15 and 16 of Volume I, there are twelve academics, ten crime writers, eight translators and six publishers, in addition to individuals who describe themselves as exercising more than one of the above professions. There are also five journalists, five librarians, two secondary school teachers, two engineers, one specialist on railway networks, a restaurant owner and a person who is simply described as "lectrice." What unites the group is of course a passion for crime stories. They are all "amateurs de polar," though many have vested interests in the continuing health of the genre. In a sense the Dictionnaire stands as a monument to the success of an industry, which requires the maintenance and promotion of a special brand. Thus there will have been a touch of business acumen bearing on the decision to allocate five pages in Volume II to the prizes awarded each year to French-language crime writers, of which there are no less than sixteen (Mesplède 2007, 11: 501-6). The sums involved are small, usually under 1,000 euros, the idea being to scoop a maximum return on the investment in terms of publicity and exposure. Four, including the best known Prix du Quai des Orfevres, are awarded to authors of unpublished manuscripts, indicating that the French crime fiction industry not only understands that celebrating success is a good business practice but also that commercial security depends on strategic interventions, which are here aimed at the identification and support of burgeoning talent. ${ }^{9}$

7 Annual prize-giving is one of a number of elements involved in the promotion and marketing of crime fiction in France; others are specialist (mostly online) journals, literary festivals, media appearances, and writing workshops. These activities mirror what happens in the publishing industry generally, but in respect of crime, or indeed of any popular genre, they are marked by the faint stigma of cultural inferiority. Like the contributors to the Dictionnaire, the actors in these arenas hail from different professional and social milieus. Again, it would be foolish to argue that mainstream French fiction is in any way less democratic than the crime genres, and there are many who enjoy reading both; however, it is possible to surmise that the passion for reading crime might in some cases be accentuated by tinges of resentment born of a perceived cultural inferiority, or in others exalted by the mildly rebellious spirit of those who see themselves as living on the margins. Whether or not this aggravated inclusivity is in itself a fiction, any attempt 
to elaborate an academically-oriented aesthetics of crime writing will be obliged to work with the grain of a popular reading consciousness.

Another striking feature of the Dictionnaire is its resolute internationalism. It is especially generous towards English and American writers, allocating three pages or more to Eric Ambler, John Dickson Carr, Patricia Highsmith, Graham Greene and James Ellroy. Conversely, Simenon is afforded less than one page of comment, and even Jean-Patrick Manchette, perhaps the most influential of modern French crime writers, receives only two-admittedly laudatory-pages. This tilt in favour of English-language crime writing reflects the longstanding popularity in France of American and English crime authors, from the trailblazing, post-war years of the imported, hard-boiled classics of Hammett, Chandler and McCoy to the contemporary era of Mary Higgins Clark, Patricia Cornwell, James Patterson, Harlan Coben and James Ellroy, who tend to be more prolific and sell at least as many copies of each new novel as the big guns of the French polar, Fred Vargas, Jean-Christophe Grangé and Caryl Férey. ${ }^{10}$ It also anticipates the boom in international crime fiction over the past five years, typified in literature by the rise to prominence of the "Nordic Noir" and in television by public appetite for well crafted, serial crime narratives stretching out over many weeks, which are later sold as box sets. Notable examples of the latter include in America the HBO series The Wire, which ran over five seasons from 2002 to 2008, and in Europe the Danish cult series The Killing, which ran over three seasons from 2007 to 2012.

9 Academic interest has been kindled by this contemporary phenomenon of a popular culture in the western world, saturated with crime narratives that have originated in certain places and register aspects of cultural specificity but are digested comfortably by international consumers. It raises two related questions, firstly on the mechanics of the operation, on how these linguistic and cultural transitions are engineered, and secondly on whether the crime story of itself, as an apparent vector for transnationalism, has at its core a set of universal properties. In this respect the dictionary entry on Agatha Christie (Mesplède 2007, 1: 379), which describes her characters in ostensibly unflattering terms as flat and stereotyped, but so much so that they are "transposables dans n'importe quelle société [...] comme les protagonistes des contes ils atteignent ainsi une sorte de vérité universelle et intemporelle, ${ }^{11}$ is instructive.

The third remarkable feature of the Dictionnaire is its propensity for transforming fictional characters into avatars. Sir Arthur Conan Doyle, who commands a respectable two pages of text, is inevitably eclipsed by his creation. The four pages dedicated to Sherlock Holmes are supplemented by a further two with the title "Holmes, Sherlock (Pastiches)," and a third entry under the heading "Holmésologie." Moriarty gets his own single-page entry, and bizarrely Conan Doyle's posthumous existence as a fictional character in crime stories written by other people is also acknowledged under a separate heading. Sherlock is not the only character in the Dictionnaire who overshadows his creator; Father Brown outdoes G. K. Chesterton, Maigret overwhelms Simenon, and Lord Peter Wimsey, Arsène Lupin and San-Antonio are all given equal billing with Dorothy L. Sayers, Maurice Leblanc and Frédéric Dard respectively.

11 The notion that crime fiction has spawned these mythical creatures that appear to enjoy a degree of autonomy presents a direct challenge to the prevailing view in university literature departments, where students are encouraged to see fictional characters as textual constructs rather than psychological entities. On the other hand, it rhymes with the funky approach adopted by Pierre Bayard, who speaks happily of his associations with 
literary characters: "Ceux-ci ne sont pas, comme on le croit trop souvent, des êtres de papier, mais des créatures vivantes, qui mènent dans les livres une existence autonome, allant parfois jusqu'à commettre des meurtres à l'insu de l'auteur." (2008: 19) ${ }^{12}$ For the moment, we can infer from the evidence supplied by the Dictionnaire that readers form bonds with fictional characters. The ensuing question concerns the nature of this engagement, specifically whether the experience of reading crime fiction is inherently more immersive than that of reading standard novels, which conventionally entails the "willing suspension of disbelief." If so, in accordance with Marie-Laure Ryan's theories of literary immersion, this would restore crime fiction to its generic source, as an offshoot of the "high realism" of the 19th-century novel.

Ryan offers a beguiling theory of the novel that takes its cue from the history of art. A pivotal moment, Ryan ascertains, would have occurred when the discovery of the laws of perspective effectively banished the neo-platonic abstraction of pre-Renaissance art. Depth-of-field drew the spectator into the world of the painting, allowing him or her to experience the objects depicted as "virtually present" (Ryan 2001: 3). This visual immersion, she argues, manifests itself through the disorientation induced by the trompe l'œil effects of the Baroque. Similar shocks would have accompanied the emergence of a literary realism in 19th-century Europe, which Tom Wolfe compares to the "introduction of electricity into machine technology" (cited in Ryan 2001: 161). Ryan explains how realism "effaced the narrator and the narrative act, penetrated the minds of characters, transported the reader into a virtual body located on the scene of the action, and turned her into the direct witness of events, both mental and physical, that seemed to be telling themselves." (Ibid.: 4) Nineteenth-century realism transformed both the relationship of the reader to the book, and of literature to society; as Ryan vividly puts it, "wide strata of society wept for Little Nell or waited anxiously for the next instalment of Dickens's serial novels." ${ }^{13}$

13 This cohabitation of the reader and the fictional character seems particularly apposite to crime fiction, where traditionally the detective is presented as a proxy for the reader. However, the equation between detective and reader, if it can be sustained, would imply that immersion in the world of a crime novel is anything but a passive experience, for the detective is a privileged character endowed with special cognitive powers. Would this imply therefore that crime fiction offers a distinctively different kind of reading experience? For the moment we might posit that keen readers of crime fiction would not necessarily be good detectives but that the reader of the crime novel is inevitably caught up in the process, operating rather like the translator is obliged to do, beneath the arc of the narrative, in the world of the text and trying to make sense of it.

\section{Reading Minds: Poe and Vargas}

Bearing in mind assumptions over the intercultural portability of crime fictions, the next question that arises concerns the possibility of a congruence between habits of reading and the practice of translation. Edgar Allen Poe's short story, The Murders in the Rue Morgue, which is considered by many critics to be the founding narrative of the genre, offers fertile ground upon which to test this hypothesis.

The story begins with a disquisition on the value of playing games as essential training for the mind, which is then followed by an episode that is commonly regarded as the archetypal illustration of detective reasoning. M.C. Auguste Dupin and his companion are 
taking their usual postprandial stroll through the dark Parisian streets. Neither had spoken for a while ("for fifteen minutes at least") when, to the astonishment of his companion, Dupin makes an apparently random, meaningless statement: "He is a very little fellow, that's true, and would do better for the Théâtre des Variétés" (Poe [1841] 1980: 110). The companion's astonishment is due to the fact that Dupin has just verbalised the very thought that in the previous instant had passed through the former's mind. Notwithstanding the comical aspect to the conversation that ensues, Dupin's methodtracking back to a chance encounter fifteen minutes previously with an errant fruiterer and his barrow-provides a model for the detective's deductive reasoning that would serve plot fiends well over the next 170 years. In studies of the crime genres Dupin is seen as the prototype of the rational, dispassionate detective. However, what impresses with regard to this incident is less the cool of his reason, and more the intensity of his performance and the extent to which he penetrates the mind of his companion. Dupin performs a routine of mental gymnastics involving a number of different moves which include: an intent reading of gesture and expression; acute insight into the minutiae of an individual's interaction with his physical environment; a precise recall of snatches of conversation from a previous day; and a trust in the intellectual bond between the two men, such that he can gamble with confidence on his companion making at specific moments in time certain phonological and cultural associations in his mind. This heterogeneous mass of observations, intuitions and deductions supplies evidence which Dupin is able to reassemble almost instantaneously, allowing him to articulate the thought of his companion, who was wondering why a theatre actor of diminutive stature had been cast in the starring role of a tragedy. This seems less an illustration of the supremacy of the discourse of ratiocination and more a kind of radical appropriation of the other's perspective on the world in its totality. Dupin operates in the manner of a simultaneous interpreter, though for the most part silently and without the help of words. This deeply embedded mutuality of vision suggests a kind of "telementation," a term which in contemporary parlance has acquired the negative connotations of "brainwashing."

16 As a postface to Poe, let us return briefly to the eulogy of games and game-playing at the very beginning of the Rue Morgue. Although Poe's narrator thinks that there is some value in the concentrated tunnel vision required for success at chess or draughts, he puts greater store in card games like whist, where attentiveness to the body language of the other players will significantly enhance performance. The successful player of whist will rely not only on his or her mastery of the rules, rules which assure the internal cohesion of the game, but also calculate how his or her partner and their opponents will react, and in this he/she takes note of the external contingencies. Again, the emphasis is on the totality of the other's perspective, as Poe's narrator puts it, "a comprehension of all the sources whence legitimate advantage may be derived" (Poe [1841] 1910: 106).

Vincent Jouve (1992) argues that characters are the primary organising principles of literary narrative. If a reader can be said to identify or empathise with a literary character, then he or she at the very least connives with what we might call a wholeworld view of the text. Crime fiction involves a journey of the mind which is both cerebral and potentially empathetic, but like any other kind of novel it presents an imagined world which, when reading, we are apprehending. The antennae of the crime reader may be twitching with anticipation before the first page is turned, the investigative experience may be more concentrated, but the presence of the reader in an imagined 
world is like that of any traveller. We start a novel, then we accept or reject it. We turn back or push on and acclimatise. This "whole-world" view of the literary text begs some interesting questions in relation to the practices of textual analysis on the one hand and translating text on the other. With textual analysis, in seminars or at conferences, or when we apply various theoretical models, we tend to fragment literature, chop up text, and although this allows us to disaggregate parts, we also lose the sense of the novel or poem as a holistic entity. The supposition advanced here is that translators, who work line by line, cannot afford to lose that sense of wholeness about a work.

If Dupin, in The Murders in the Rue Morgue, is presented as a translator of thoughts, Fred Vargas has developed two characters who interpret the world in different ways. Her favourite, le commissaire Adamsberg, is a famously irrational, intuitive sleuth, who is presented as the antithesis of reasoning machines like Dupin. And yet Vargas, like Poe, is preoccupied with the workings of the mind, deploying an arsenal of tropes (thoughts as fish, clouds, and the scattering of a flock of birds) to reflect the transience of Adamsberg's thinking. A different world-view is provided in Vargas's novels through the perspective of Adamsberg's deputy Danglard, he of the encyclopaedic knowledge and domestic woes. Their relationship is further triangulated in Dans les bois éternels with the first appearance of Veyrenc, a younger alter ego of Adamsberg from a neighbouring Pyrenean village, allowing for more extensive exploration of the Commissaire's imperturbability. ${ }^{14}$

Adamsberg's charisma is magnetic, yet he remains at a certain distance; access to his thoughts, his feelings and his life story is carefully policed by his creator. Vargas (2001: 8) deplores the recent trend in France for autofiction, introspective, self-reflective narratives that hover somewhere over autobiography and novel. In contrast her stories coil around the nuggets of popular folklore, myth, legend that she continues to unearth. Indeed no other living writer explores more deftly our reluctance to jettison superstition, and our concomitant fascination with the uncanny and the ethereal. In appraising her approach to characterisation, a useful distinction is the philosophical one between perceptsoutputs of perception, which are sense-orientated-and images-outputs of the imagination, which are mental actions. Adamsberg is sensitive to percepts, indeed he seems at times assailed by percepts. These may be habitual (his neighbour Lucio urinating in the evening against the foot of the tree in his garden), mnemonic (the antlers in his office) or motivated clues (the way the young street gangster Momo-mèche-courte laces his trainers in L'Armée furieuse). Functioning for the most part in this realm of the senses, Adamsberg is like Vargas's caveman in Petit traité de toutes vérités sur l'existence, constantly seeing the world afresh. Thus he seems remote, an alien in his surroundings, an antidote to the narcissism of the romantic poet or writer of autofiction. Yet at the same time, from the vantage point of the reader, the fluidity of Adamsberg's thinking represents instability and the precarious nature of human relations. The reader may be keen to get to know him but he seems to resist empathy. When we journey back to his childhood in Dans les bois éternels, we despair at his apparently impassive response to the cruelty inflicted on the young Veyrenc, until finally he intervenes. We learn that our hero's hands had been tied behind the back of a tree, and a sensory misapprehension or percept (this time on the part of the reader) is corrected.

Adamsberg's personality is opaque, his identity no more than a succession of more or less well remembered percepts. He is animated by the existence of curious external phenomena which drive the plots of Vargas's novels. Questions of the self are deflected, or possibly displaced; one could speculate that his creator's fascination with supernatural 
mysteries-the myths, legends and folklore-is in itself a kind of displacement. Whenever Danglard's ordered world disappoints, as it so regularly does in the novels, and we can't or don't want to find answers within ourselves, we might be tempted to look beyond science and reason and into the supernatural.

A major plank of my argument states that our experience of reading crime fiction tends to be modulated by the degree to which we immerse ourselves in the world conjured up by the words of the text. Alvin Goldman makes a distinction between what he calls suppositional imagination (S-Imagination) and enactment imagination (E-Imagination). SImagination-to suppose that something could happen-invokes the minimum investment of self in the fictional world. E-imagination is a more elaborate, committed process which involves trying to create in one's own mind a selected mental state, or as Goldman puts it, "a rough facsimile" (2006: 42) of such a state through the faculty of imagination. Vargas's fiction would indicate that Goldman's categories are not hard and fast. She invites and obstructs an immersive practice of reading. Of her two investigators, the one, mysterious and enigmatic, invites an empathy which can never be fulfilled, while the other, Danglard, whose predicaments are depressingly familiar, pleads for sympathy (rather than empathy). Yet both are privileged interpreters of Vargas's fictional universe. As a perpetual outsider, Adamsberg assumes a very readerly presence but one more akin to a literary critic, picking bits out here and there, chasing hares, forming judgements, following obsessions, but not required to render the totality of the reading experience. The suspicion would be that most translators feel they need to behave more like Danglard than Adamsberg, worrying about the esoteric references they don't immediately understand. And yet theorists of translation have consistently stressed that good translators must go beyond the literal transmission of sense into the area of cultural difference and cultural exchange.

In his study of literary translation Jeremy Munday focuses on process, specifically on the identification of key points where evaluative decisions must be made, which he describes as "those places in a text [...] where the translator or interpreter's intervention and subjectivity are potentially most telling" (2012: 1-2). Munday uses the interesting term "translator and reviser." One of his case studies is David Bellos' translation of Georges Perec's $\mathrm{La}$ Vie mode d'emploi, a ferociously difficult novel suffused with intertextual references and hidden patterns. Faced with this challenge Bellos could either produce a text of accurate non-sense or embark on some revision. He did the latter, explicating allusions and references that are deliberately implicit in the source text, and in so doing attracting the wrath of Perec scholar Bernard Magné. Magné criticised Bellos for this "textual exhibitionism" (Munday 2012: 121) which, in his eyes, destroys the sophisticated ploy by which Perec makes certain readings visible to only a select few readers. However, for Bellos (2011: 332) the translation must carry the "same information" with the "same force" as the source text. As he explains in his own book on the art of translating, pertinently subtitled "translation and the meaning of everything," Bellos the translator is guided by the principle of telementation, a term which, as indicated above, is now used principally by religious cults to describe a "fusion of minds" but was originally coined by Ferdinand de Saussure in the Cours de linguistique générale to denote the transmission of thought within a synchronic system of language (2011: 325). So the translator, like the reader, must embrace a whole-world view of the text. 


\section{The Reader Detective and the Empowered Citizen: Bayard and Boltanski}

23 To the best of my knowledge, Pierre Bayard is the first commentator since Tzvetan Todorov in the mid-1960s to develop a fully-fledged aesthetics of the crime narrative. The principle upon which Bayard's "critique policière" is founded is one of direct intervention in the world of the text. In this he effectively renews the pact between detective writer and reader established by the Golden Age theorist S. S. Van Dine (1928: 16-18), according to which the reader must be supplied with the same evidence at the same times as the fictional detective, thus allowing him or her to compete with the sleuth on a level playing field. Most commentators, mindful perhaps of the fact that very few exponents of classic detective mysteries ever managed to obey Van Dine's dictum, have merely dipped their toes in the water; Bayard, on the other hand, like Gaston Leroux's precocious protagonist Rouletabille, takes a plunge. In fact he takes several plunges.

In Qui a tué Roger Ackroyd ? (1999) he recognises the technical brilliance with which Agatha Christie designed a plot that for much of the novel can accommodate numerous potential outcomes. However, on the basis of evidence given in the text he finds fault with her choice of solution, before proceeding to identify the real murderer (who has escaped scot free for the best part of seventy years!) again on the basis of evidence contained in the text. In Enquête sur Hamlet (2002) he identifies a logical implausibility, arguing that the custom in Renaissance theatre of entertaining the audience with a prelude, consisting of pantomime performances of key scenes from the main play to follow, neutralises the impact of the famous scene in which the death of Hamlet's father is re-enacted and effectively exonerates Claudius. And in the opening section of L'Affaire du chien des Baskerville (2008) he alights on several instances in the adventures of Sherlock Holmes where the detective, he contends, makes serious errors, all of which may be attributed to deviations from the blueprint for successful detection laid out in the opening pages of $A$ Study in Scarlet. Then, much in the manner of a translator, he advances linearly through the text of The Hound of the Baskervilles, meticulously sifting information and building a complex mental picture of the fictional world. Here the reader-detective is stimulated by an abundance of clues, an extravagance which Bayard attributes to the vanity of Sherlock (rather than to the imagination of Conan Doyle): "Son goût pour les solutions complexes et surprenantes fait qu'il est toujours possible de trouver de nouveaux indices et de les mettre au service d'une autre construction d'ensemble plus inventive que celle du détective" (Bayard 2008: 63). ${ }^{15}$

What elevates Bayard's exegeses above pleasant diversion is the intellectual precision with which each facet of his theory is outlined. His view of literary characters as autonomous, flesh-and-blood creatures rather than imprisoned textual constructs, which would be preposterous to some, is explained in terms of the conscious and unconscious mind. Consciously of course we know that fictional characters do not exist, but they have a different relationship to the unconscious mind. Although the Unconscious is impervious to ontological distinctions, it does register the effect that others, real or unreal, have on the psyche. Bayard points out that many people are deeply affected at stages in their lives by literary characters. Citing Don Quixote and Madame Bovary he argues that the Unconscious can endow fictional characters with a type of existence unbound by the contingencies of time and place, meaning that fictional characters may feature more 
prominently in a reader's life than some acquaintances of the real world. Moreover, the exoticism of the literary character evokes the chance encounter, the excitement of meeting someone new, and potentially threatening.

Bayard's typically creative reading of The Hound of the Baskervilles is predicated on the complexity of just such a relationship between a real person and a fictional character, in this case that of the author and his most famous creation, whom he had resurrected to star in the novel. At one point he pans away from his near relentless pursuit of the real culprit-which is neither a large dog nor its owner-in order to frame his methodology within a broader theoretical context. Borrowing from Thomas Pavel's work on the boundaries between the real and the fictional, he pitches the debate over how readers respond to the literary text at an ontological level. Bayard envisages a spectrum. At one pole would be situated the pure ségrégationnistes, who would consider the content of a fictional text as a product entirely of the imagination and therefore divested of any truth values. At the other lodge the intégrationnistes, who believe that there is no ontological difference between the content of a fictional text and non-fictional descriptions of the universe. Bayard merrily outs himself as a radical intégrationniste and proceeds to examine the emotional turbulence that characterised the relationship between Sir Arthur Conan Doyle and Sherlock Holmes, supporting his argument with reference to other " intégrationniste" features, notably the figure of the golem in fantasy literature which, he argues, is such a vivacious entity that it frequently escapes the clutches of its creators (Bayard 2008: 114-20).

Although Bayard is himself a stimulating reader of literature, his prescription is less anarchic than it might first appear. Like many modern theorists, he insists on the incompleteness of the literary text and on the role of the reader, which is to provide "la clôture subjective." However, if the reader is to be afforded the status of co-creator, she must earn her stripes, for this "travail de complément" should be carried out with "la plus grande rigueur possible" (Ibid.: 77). Bayard does not elaborate upon what this "rigueur" might entail, but the inference is that it can only derive from years of more disciplined study of literature and training in critical theory. It might also explain why Bayard concentrates his efforts on reading canonical texts and also why he does not broach more radical experimentation with the idea of literary or artistic co-creation, which is implicit in the current trend for "fan fiction."16

This emphasis on subjectivity that characterises Bayard's approach precludes much interrogation of how crime fiction, especially in its more contemporary forms, may articulate wider political and societal concerns. However, these are precisely the questions that animate sociologist Luc Boltanski's investigation (2012) into the prominence and indeed the popularity of the genre in 20th-century western society. Boltanski's thesis is that crime narratives-he foregrounds the conventional mystery story or whodunit, and the spy novel-have played a significant role in shaping social realities. Echoing the work of Jacques Dubois (1993), he argues that the raison d'être of the detective and spy novels is to demarcate and profile the tropes of the "énigme" or puzzle, and of the "complot" or conspiracy. These features, he insists, are part of a hidden reality, occluded from view by what he calls the "régularités sociales" of ordinary life. The stated purpose of crime fiction is therefore to expose secrets and disclose suppressed knowledge, and this is why even the most apparently anodyne detective story will always raise questions about the society in which it is read. Boltanski outlines his ideas in the 
course of an analysis of just such an apparently insignificant mystery story, G. K. Chesterton's The Blue Cross:

L'énigme est donc une singularité (puisque tout événement est singulier) mais une singularité ayant un caractère que l'on peut qualifier d'anormal, qui tranche avec la façon dont les choses se présentent dans des conditions supposées normales, en sorte que l'esprit ne parvient pas à inscrire cette inquiétante étrangeté dans le champ de la réalité. (Boltanski 2012: 22) ${ }^{17}$ that cement the joints in his argument. He alludes to the birth of psychiatry at the end of the 19th century and to the concomitant development of the concept of paranoia. This is turned to positive effect through the reading of detective fiction, which legitimises feelings of paranoia and then paradoxically, by co-opting the reader into the process of detection, provides the opportunity for a literary cure. Paranoia is justified, or at least exorcised, by detective-like behaviour. With the "complot," individual paranoia is extended to the collective, and again negative assumptions relating to conspiracy theorists are transformed into positive values. Crime fiction is therefore viewed by Boltanski not only as a prominent feature of our global culture-"les formes narratives les plus répandues, et cela sur un plan planétaire" (Ibid.: 16)-but also as an extraordinary force for good. He points out that, although classical crime fiction was seen as intrinsically conservative in its mission to restore the natural order, the genre has never established itself under autocratic regimes. The figure of the detective is thus infused with political idealism. And here the circle is closed, as Boltanski's notion of the eternal outsider as paragon of democracy echoes the celebration of the independent enquiring mind, which was exquisitely captured in Régis Messac's pioneering study of the genre ([1929] 1975).

\section{Conclusion}

Boltanski's argument, that crime fictions pierce the veneer of everyday life to reveal the hidden complexities of modern society and also evoke means of re-empowering concepts of citizenship, is compelling. His work also constitutes an important step in unravelling the enigma of contemporary crime fiction-concerning the vertiginous rate at which it continues to reach global audiences-by developing the idea that the genre provides simulations of social realities that the reader may experience as well as analyse. Throughout this essay, stress has been put on the notion that each encounter between the reader and the crime narrative enacts a renewal of the contract between producer and consumer, based on the shared knowledge that the reading itself will always be a surrogate investigation, a hermeneutic quest for truth, and that this process is germane

Itinéraires, 2014-3 | 2015 
to the genre. Moreover, critical practices geared towards crime fiction should at least in part reflect the importance of these series of encounters shared between the fictional character and the reader, which in themselves approximate to the series of decisions and choices that await the literary translator of the text. Reading crime fiction is in many respects a transactional process. The most successful crime fictions-those produced by Nesbǒ, Vargas or Rankin-promote a brand, often personified by a recurrent character with whom a readership can cultivate longstanding relationships and thus profit from the attractions of what theorists of popular literature term "la sérialité." Ultimately the author is paid, the translator is paid and the reader pays, for the thrill of being taken to new and dangerous places, in the company of someone who is more or less well known.

\section{BIBLIOGRAPHY}

Bayard, Pierre, 1999, Qui a tué Roger Ackroyd?, Paris, Minuit.

-, 2002, Enquête sur Hamlet : le dialogue de sourds, Paris, Minuit.

-, 2008, L'Affaire du chien des Baskerville, Paris, Minuit.

Bellos, David, 2011, Is that a Fish in your Ear? Translation and the Meaning of Everything, London, Penguin.

Boltanski, Luc, 2012, Énigmes et complots : une enquête à propos d'enquêtes, Paris, Gallimard.

Dubois, Jacques, 1993, Le Roman policier ou la Modernité: le texte à l'œuvre, Paris, Nathan.

Ducas, Sylvie, 2013, La Littérature à quel(s) prix? Histoire des prix littéraires, Paris, La Découverte.

Dumasy, Lise (ed.), 1999, La Querelle du roman-feuilleton : littérature, presse et politique, un débat précurseur (1836-1848), Grenoble, ELLUG.

Forshaw, Barry, 2014, Euro Noir: the Pocket Essential Guide to European Crime Fiction, Harpenden, Pocket Essentials.

Goldman, Alvin, 2006, "Imagination and Simulation in Audience Responses to Fiction," in

S. Nichols (ed.), The Architecture of the Imagination: New Essays on Pretence, Possibility, and Fiction, Oxford, Oxford University Press, p. 41-56.

Gorrara, Claire, 2012, French Crime Fiction and the Second World War: Past Crimes, Present Memories, Manchester, Manchester University Press.

Holmes, Diana, 2013, “The Mimetic Prejudice: the Popular Novel in France," in D. Holmes and D. Looseley (eds), Imagining the Popular in Contemporary French Culture, Manchester, Manchester University Press, p. 85-122.

Hutton, Margaret-Anne, 2013, French Crime Fiction 1945-2005: Investigating World War II, London, Ashgate.

Jenkins, Henry, 2006, Fans, Bloggers and Gamers: Exploring Participatory Culture, New York, New York University Press.

Jouve, Vincent, 1992, L'Effet-personnage dans le roman, Paris, PUF. 
Lacôte-Gabrysiak, Lylette, 2010, “C'est un best-seller !", Communication, no. 27/2, [En ligne], 31 mars 2010, http://communication.revues.org/3130. DOI: 10.4000/communication.3130. Consulted 29 January 2015.

Le Monde newspaper, 15 March 2007: http://www.lemonde.fr/livres/article/2007/03/15/desecrivains-plaident-pour-un-roman-en-francais-ouvert-sur-le-monde_883572_3260.html. Consulted 28 January 2015.

Mesplède, Claude (dir.), 2007, Dictionnaire des littératures policières, Vols I and II, Nantes, Éditions Joseph K.

Messac, Régis, [1929] 1975, Le Detective Novel et l'influence de la pensée scientifique, Geneva, Slatkine Reprints.

Migozzi, Jacques, 2005, Boulevards du populaire, Limoges, PULIM.

Munday, Jeremy, 2012, Evaluation in Translation: Critical Points of Translator Decision-Making, London, Routledge.

Platten, David, 2011, The Pleasures of Crime: Reading Modern French Crime Fiction, Amsterdam, New York, Rodopi.

Poe, Edgar Allan, [1841] 1980, “The Murders in the Rue Morgue," in J. Symons (ed.), Selected Tales of Edgar Allan Poe, Oxford, Oxford University Press.

Raynal, Patrick, 1995, “Le roman noir est l'avenir du roman,” Esprit, no. 209, p. 77-96

—, 1997, “Le roman noir est l'avenir de la fiction," Les Temps Modernes, no. 595, p. 88-99.

Ryan, Marie-Laure, 2001, Narrative as Virtual Reality: Immersion and Interactivity in Literature and Electronic Media, Baltimore, Johns Hopkins University Press.

Van Dine, S. S., 1928, “Twenty Rules for Writing Detective Stories," American Magazine, September 1928, p. 16-18.

Vargas, Fred, 2001, Petit traité de toutes vérités sur l'existence, Paris, Librio, Viviane Hamy.

\section{NOTES}

1. Patrick Raynal (1995 et 1997). Raynal was the editor of the Série noire (1994-2004).

2. Le Monde [newspaper], 15 March 2007: http://www.lemonde.fr/livres/article/2007/03/15/desecrivains-plaident-pour-un-roman-en-francais-ouvert-sur-le-monde_883572_3260.html (consulted 28 January 2015).

3. http://www.metronews.fr/culture/avant-quais-du-polar-un-genre-qui-ne-connaitdecidement-pas-la-crise/mndb!CwGMpuMjecmdc/ (consulted 28 January 2015).

4. Cited in Forshaw (2014: 162): "Such energy, such variety, such cleverness and such rich characterisation among the novels of this group. And such excellent translations too."

5. This gradual emergence is evidenced in Lylette Lacôte-Gabrysiak's empirical study of French bestsellers over the period 1984-2004. See Lacôte-Gabrysiak (2010).

6. The œuvres of Daniel Pennac, Jean-Claude Izzo and more recently Fred Vargas are often seen as having transcended the genre. Crime novelists Jean Vautrin, Sébastien Japrisot and Tonino Benacquista have all enjoyed considerable success as screenplay writers, adapting their own work or that of others for the cinema. Jean-Patrick Manchette, the guru of the néo-polar, is cited by Jean Echenoz, himself a Goncourt winner and highly esteemed contemporary writer, as a singular influence over the latter's career, and Pierre Lemaître, having won numerous accolades 
for his crime novels, Travail Soigné (2006) and Alex (2011), was awarded the 2013 Prix Goncourt for $A u$ revoir là-haut, his novel of the Great War.

7. This article will refer to the updated 2007 edition.

8. See two critical works on this subject published recently in English: Gorrara (2012) and Hutton (2013).

9. Prizes awarded to crime fiction are a minute fraction of the 2,000 awarded annually to French writers and poets, which, in terms of sheer scale, is unique to France. This annual cycle of prizegiving is, according to Sylvie Ducas (2013), a complex commercial enterprise, which has changed fundamentally public perception of the status of literature and literary authors. Those with the potential to write bestsellers are protected, whereas others, who, in previous eras, might have been venerated as literary greats risk marginalisation or, worse still, obscurity.

10. The three main sources of information-LivresHebdo (www.livreshebdo.fr), L'Express (www. lexpress.fr/culture/livre/palmares-livres_1579196.html) and, since 2004, Edistats ( www.edistat.com)-indicate that a bestselling polar should reach 500,000 sales.

11. "transposable to any kind of human society [...] like the characters of folk tales they reach a sort of universal, timeless truth." Where I have translated from French sources, the translations are my own unless otherwise stated.

12. "These are not, as people too often deem them to be, paper entities, but living creatures, who lead autonomous lives within the books, sometimes going so far as to commit murders unbeknownst to the author."

13. Ibid. The pre-eminence accorded to the reader of the roman feuilleton has attracted numerous scholars: see especially Dumasy ed. (1999) and Migozzi (2005). For a concise analysis of the reception of the popular novel in France see Holmes (2013).

14. For an extended discussion of characterisation in Vargas's work, see Platten (2011: 227-32).

15. "His preference for complex, surprising solutions means that it is always possible to find new clues and to use them to construct an alternative scenario, which is more inventive than that of the detective."

16. For an informed discussion of the phenomenon of "fan fiction," see Jenkins (2006).

17. "The puzzle is therefore a singularity (since any event is singular) but a singularity of a nature that could be defined as abnormal, which breaks with the way that things appear under supposedly normal conditions, such that the mind is unable to register this disturbing peculiarity as a part of reality."

\section{ABSTRACTS}

This article explores the hegemonic status enjoyed by the crime novel in the contemporary era, a genre which, in contrast to the literary mainstream, continues to flourish. It suggests that the development of a body of research on crime fiction has resulted in the widespread acceptance of a finite number of unassailable generic qualities. One of these, the heuristic function of the crime narrative, plays a crucial role with regard to two questions that have stimulated much interest recently among critics. These concern firstly the relative ease with which crime fiction, unlike other literary genres, seems able to migrate from one national culture to the next, and secondly its capacity to engage with notions of the real or indeed with topical issues, even in those instances where the referential aspects of the text in question are muted. With reference to the 
monumental Dictionnaire des littératures policières edited by Claude Mesplède, and drawing on the influential studies of Pierre Bayard and Luc Boltanski, the article offers fresh readings of the work of Poe and Vargas.

Cet article explore le statut hégémonique du roman policier à l'époque contemporaine, dont la santé robuste contraste avec d'autres littératures, y compris la " grande littérature ». Il suggère que la recherche croissante sur le sujet, qui a fixé certains traits génériques inébranlables dont l'un, à savoir la fonction heuristique du récit policier, joue un rôle primordial à l'égard de deux questions qui intéressent la critique. En premier lieu, il s'agit du rayonnement de la fiction policière, laquelle semble répondre mieux que d'autres littératures nationales aux goûts des lecteurs issus d'autres cultures. En second lieu, l'article montre que le roman policier est plus à même d'être en phase avec le réel ou l'actualité, sans pour autant afficher beaucoup d'éléments référentiels. En s'appuyant sur le Dictionnaire des littératures policières (dir. Claude Mesplède), et sur les essais de Pierre Bayard et de Luc Boltanski, l'article revisite les œuvres de Poe et de Vargas.

INDEX

Mots-clés: roman policier, théories littéraires, fonction heuristique, lecteur, traducteur, personnage, Poe (Edgar Allan), Vargas (Fred), Bayard (Pierre)

Keywords: crime novel, literary theories, heuristic quality, reader, translator, character, Poe (Edgar Allan), Vargas (Fred), Bayard (Pierre)

\section{AUTHOR}

DAVID PLATTEN

University of Leeds 